PUBLIC HEALTH RESEARCH

\title{
The Policy Analysis of Non Transmitted Disease Integrated Post In The Regency of Sukoharjo Indonesia
}

\author{
Sri Sugiarsi* and Erna Adita Kusumawati \\ Health Higher School of Mitra Husada Karanganyar Indonesia. \\ *For reprint and all correspondence: Sri Sugiarsi. Health Higher School of Mitra Husada Karanganyar \\ Indonesia. \\ Email :sri.sugiarsi14@gmail.com
}

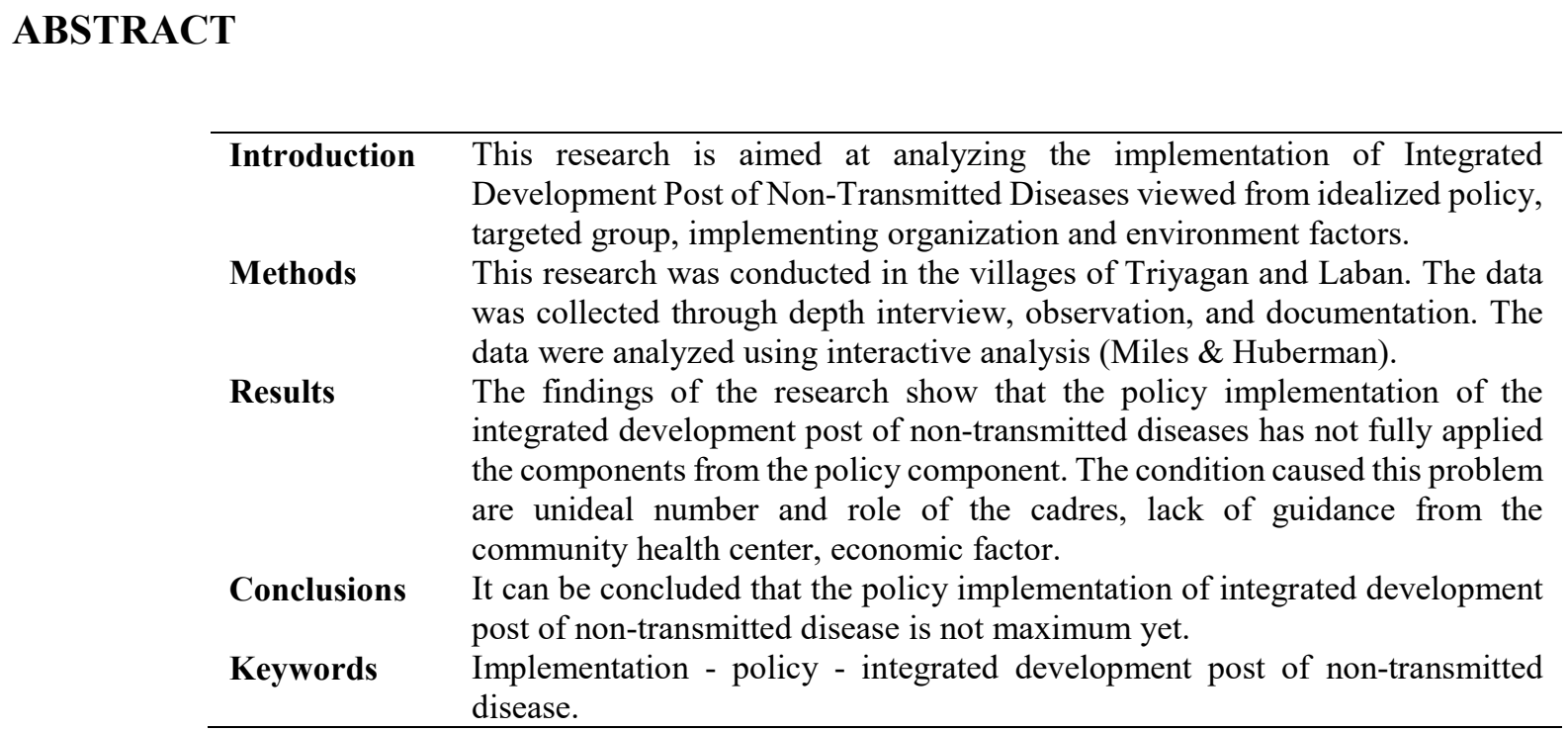

Article history:

Received: 19 October 2019

Accepted: 29 March 2021

Published: 1 September 2021 


\section{INTRODUCTION}

The proportion of death due to non-transmitted disease in Indonesia increases. Based on the result of the Household Health Survey in 1995, 2001, and that of Basic Health Research in 2007, the proportion of death due to non-transmitted disease always increases started from 41.7\% (1995), 49.9\% (2001), and reaches $59.5 \%$ (2007). There is an increase in the prevalence of non-transmitted disease, i.e. hypertension started from $7.6 \%$ in 2007 becomes $9.5 \%$ in 2013. The same trend happens in stroke which touches $12.1 \%$ from $8.5 \%$ in 2007 and that of diabetes mellitus reaches $2.1 \%$ in 2013 from $1.1 \%$ in $2007 .^{1}$

The increasing of non-transmitted disease also happens in Sukoharjo Regency in which there are 2,750 cases in $2015,3,150$ cases in 2016, and 3,805 cases in 2017 . The increase of prevalence of non-transmitted disease brings significant impact toward the increase of the health financing burden that must be borne by the state and the society. People with non-transmitted disease require relatively more expensive feed, particularly if the condition develops into chronic and complications occur. Non-transmitted diseases cost a lot when it is compared to the highest medication costs of all infectious diseases. Non-transmitted diseases countermeasures in Indonesia are conducted through integrated development post of non-transmitted disease and the non-transmitted disease guidance is considered as one of targets and indicators of nontransmitted disease control. The activities of integrated development post of non-transmitted disease in the community and non-transmitted disease guidance in Community Health Center are promotive and preventive efforts done through an early detection of non-transmitted disease risk factors. ${ }^{2}$ The non transmitted disease integrated post might be difined as activities of monitoring and risk factor early detection of integrated non transmitted disease (cardiovascular disease, diabetes, lung disease, asthma, and cancer) which are managed by society through the guidance of Community Health Center.

Based on the review of related literature, the implementation of integrated development post of non-transmitted disease in almost all regions in Indonesia still encounters various problems, such as low target coverage $(<40 \%)$, less role cadres, no health education, no tools of total cholesterol and triglyceride, lack coordination between cadres and health officers, less commitment from community health center as guiding officers, less cooperation across sectors in integrated development post programs, and unmotivated community to become cadres. ${ }^{3}$ There is a relationship between the socialization of integrated development post and the activeness of integrated development post visit $(\mathrm{p}<0.05)$. Respondents having low knowledge have an opportunity up to 61.5 times in terms of not utilizing integrated development post compared to those having high knowledge. ${ }^{4,5}$ It needs communication between policy makers and target groups through policy socialization of integrated development post that later will motivate the target groups to involve in the policy propose since the policy content is fulfilled the needs of target group health. ${ }^{6,7}$

The working area of Community Health Center of Mojolaban covers 15 villages and there are merely two villages having integrated development post of non-transmitted disease, i.e. Triyagan village and Laban village. Those numbers are not ideal yet. It is still far from the coverage rate targeted by the government in which is there is at least one post in each village. Based on the preliminary survey toward the implementation of integrated development post of non-transmitted disease policy, it is found out that the Community Health Center has conducted socialization of integrated development post of non-transmitted disease through regular meetings. However, it has not worked optimally to motivate the target groups to establish the integrated development post. It is proved that there are merely two integrated development post that have been set up. The coverage of people who utilize integrated development post of non-transmitted disease is still low $(10.8 \%)$. The limited number of health officers is a difficulty for Community Health Center to serve more non-transmitted disease posts. The target groups as policy implementers have tried to provide non-transmitted disease posts cadres. However, it has not met the recommendation in the implementation of non-transmitted disease posts. Those conditions cause the implementation of nontransmitted disease post policy has not run maximally. The focus in this research is the policy implementation of non-transmitted disease post through components of idealized policy, target groups, organization implementers, and environmental factors. This research is aimed at analyzing the policy of integrated development post of non-transmitted disease in the work area of Mojolaban Community Health Center, Sukoharjo Regency.

\section{METHODOLOGY}

This research is a qualitative research though a case study approach conducted in Triyagan and Laban villages in the work area of Mojolaban Public Health Center Sukoharjo in 2018. The informants were selected through purposive sampling consisting of the head of integrated development post of nontransmitted disease, four cadres, public health officers, the members of non-transmitted disease post, and the head of Community Health Center. Data collection was done through in-depth interviews and observations. The data analysis technique used interactive analysis (Miles \& Huberman) covering 4 stages, i.e. data collection, 
data reduction, data display, and drawing conclusions. Specifically, the data analysis in this research was conducted through several stages: 1) noting all phenomena found in the field through observation, interview, and documentation; 2) examining the field note of observation, interview, documentation study, and classify the data which were considered as important and that of not, for which this activities were repeated to check for possible errors in the classification; 3) describing data that had been classified by paying full attention to the focus and purpose of the research; and 4) making final analysis in the form of research report.

\section{RESULTS}

Table 1 The Data Display of Policy Implementation of Integrated Development Post of Non-transmitted Disease in the Villages of Triyagan and Laban

\begin{tabular}{lcccc}
\hline No & & Category & & Qualitative Data \\
\hline 1 & The & ideal & of & a.
\end{tabular}
implemented policy transmitted disease was the target groups communicated with the village midwife and the Community Health Center to establish integrated development post of non-transmitted disease in their environment since the Community Health Center had carried out socialization of non-transmitted disease post through meetings with health cadres so that they were motivated to establish the post

b. The target group felt that their health needs had been fulfilled with the existence of the non-transmitted disease post. The community accepts the non-transmitted disease post well

2 Target groups

a. Target groups were healthy people, had risks, and suffered from nontransmitted disease aged 15 years old and over.

b. The availability of human resources (post cadres) was only 4 people. There was no management structure and there was no division of cadre roles.

c. Most cadres did not understand the tasks that must be carried out during the implementation of the integrated development post. The cadres had been trained for merely 2 times so they had not been skillful. In this case, the Community Health Center was responsible and obliged to carry out regular training.

d. The ability of the target group to provide and allocate financial resources for the implementation of integrated development post of non-transmitted disease was insufficient. The post got cash money from the citizen association (according to the agreement between cadres and citizen association) which was worth $100,000.00$ rupiahs. This was considered insufficient, even though the target group who wanted to check was also charged 2,000.00 up to 10,000 rupiahs.

e. Infrastructure, building, health check tools, examination of blood sugar, total cholesterol, triglycerides, IVA examination, drugs were relatively complete. The book recording the result of activities was also available. Some facilities were provided by Community Health Center

$3 \quad$ Implementing organization (roles and

a. The officers of Community Health Center: did medical examinations, gave technical guidance toward cadres during the action.

performance of organization that is in charge in the policy implementation)

b. Roles of cadres: provided the place and schedule, conducted selfobservation / data collection with officers, measured non-transmitted disease risk factors

c. The duty of non-transmitted disease post cadres was still global. It had not been sorted out

d. Head of village: there were no direct guidance and support toward the integrated post

e. The performance of the cadres was quite good, as they were responsible from the preparation up to recording and reporting.

4 Environment factors (culture, economy, and politic)

a. Weekly and monthly recitation had become a culture for the people of Triyagan and Laban. Likewise was monthly social gathering activity. After those activities, it could be held immediately health examination, consultation \& counseling.

b. Economic conditions became people's problems to be inactive in the post activities. Although in terms of cost, it was not too expensive. The 
integrated post could not accept people who would pay through Health Insurance Board, so they must have paid directly.

c. Some cadres were wives of village officials / stakeholders. Politically, it had an influence on the implementation of the policy. Communities tended to follow what was suggested

\section{DISCUSSION}

The interaction pattern that was proposed by the policy makers was aimed at supporting, influencing, and stimulating the target groups to implement the policy. The policy of integrated development post of non-transmitted disease was a form of Communitybased Health Efforts carried out by, from and for the community. Based on the findings, it could be stated that the socialization of non-transmitted disease post had been conducted by the Community Health Center and successfully motivated the community to establish non-transmitted disease integrated post. The result of interview was as follows:

The non-transmitted disease integrated post was established based on residents' agreement in the villages of Triyagan and Laban after many times getting socialization about non-transmitted diseases and that of how to control them from the health center during regular meetings of citizen association. Residents felt the benefits. The agreement was conveyed by residents to the health center and Regency Health Office.

The residents' agreement was followed up by the health center and Sukoharjo Regency Health Office which was related to the technique of organizing the non-transmitted diseases post; starting from the procurement of complete facilities to the determination of the amount and source of funding, and cadres. This was in line with the theory of public policy implementation of ${ }^{8,4}$ saying that policies will run optimally and will be influenced by ideal policies. Based on the results of the interview related to the contents of the policy of nontransmitted diseases integrated post in meeting the needs that the community felt to be fulfilled in terms of health examination and counseling.

The target groups, as policy executors, had become a policy implementer, one of them was by providing cadres of non-transmitted disease integrated post. The number of cadres was not suitable with the recommended number of at least 5 cadres. The role of cadres had not been divided into more specific ones, such as encouraging cadres, monitors, educators, and coordinators. Those conditions certainly would be obstacles in the policy implementation of non-transmitted disease integrated post optimally. ${ }^{9}{ }^{10}$ states that the role of active cadres is related to the utilization of nontransmitted disease integrated post. Cadres who can encourage citizens to conduct examinations nontransmitted disease integrated post will help the community to improve awareness of the importance of preventing non-transmitted disease. The interview was as follows:

The number of cadres was only 4 people by which not all of them had received training in the implementation of non-transmitted disease integrated post. Cadres had not been able to understand the task during the implementing the non-transmitted disease integrated post. Cadres merely encouraged citizens, measured weight \& height. There was no courage to do periodic counseling. This was an obstacle in the implementation of non-transmitted disease integrated post if the health officers were unable to attend.

The policy implementers of nontransmitted disease integrated post in Mojolaban Health Center were the cadres and health officers of fostered fields. The cadres had been responsible for carrying out their duties as reflected in the good performance evaluation. The cadres had encouraged the targets by giving information about time and place. However, the cadres had not been able to carry out counseling, education, motivation and following up on referrals from the health center. This has not met with the guidelines for implementing the non-transmitted disease integrated post. ${ }^{11,12}$

The role of community health care officers had to accompany the cadres during the implementation until the cadres could handle their duties independently particularly in measuring blood pressure, measuring Body Mass Index (BMI), and being able to record, report and refer. However, their performance was insufficient. This was due to the lack of health officers to be placed in the post. ${ }^{13,14}$ says that there is a relationship between the role of health officers and the use of integrated health post. If the health officers are assigned to carry out the activities, the people tend to carry out health checks in the post. The result of the interview related to the implementation of integrated health post was as follows:

The Health Center had not yet conducted training for cadres related to the preparation of work plans, information provision to targets, interviews, and recording. This was merely due to human resource limitations. However, cadres had been trained about non-transmitted disease and the process of implementing the non-transmitted disease integrated post. Cadres had understood it very well. 
The activities of non-transmitted disease integrated post were carried out through 5 service stages. The role of health officers had not been maximal related to technical guidance for cadres \& coordination with stakeholders (head of department \& subdistrict head). The support from the village head was still insufficient especially in relation to financial support.

Based on the findings, the facilities and infrastructure related to the implementation of the non-transmitted disease integrated post had been available, such as abdominal circumference measuring instrument, height measuring instrument, digital tensimeter, body fat analyzer, Peak flow meter, sugar level measuring instrument, total cholesterol and triglyceride. This showed that the target groups had readiness to implement the nontransmitted disease integrated post. However, the obstacle in implementing the policy was related to the fund provision for implementing the nontransmitted disease integrated post. So far, it still relied on the direct fund from residents who wanted to be examined and cash donations from citizen associations. The results of this research are in line with, ${ }^{15}$ stating the completeness of facilities and infrastructure is very important in supporting the implementation of non-transmitted disease integrated post. Thus, it can be concluded that the non-transmitted disease integrated post in Triyagan and Laban villages has been implemented according to the technical guidelines.

The environmental factors would influence the implementation of policies as well. The nontransmitted disease integrated post implemented in the community was influenced by community activities that had become a culture in the villages of Triyagan and Laban. Those activities are recitation and social gathering of the citizen associations. Those activities affected residents' participation in the activities of non-transmitted disease integrated post. It was found that there had been an agreement that the activities of non-transmitted disease integrated post were carried out after social gathering and recitation activities. Thus, it could be ascertained that the participants tended to be active in utilizing the program. However, the obstacle in implementing the policy was that the economic condition which was not so good that the participants had to spend money between 10,000.00 rupiahs up to $25,000.00$ rupiahs to get health services. Health officers should be able to facilitate the community to pay through Social Insurance Administration Board or Indonesian Health Card. If non-transmitted disease integrated post could be implemented optimally, the risk factors of nontransmitted disease could be minimalized. ${ }^{15}$ The interview was as follows:
The residents had routine activities in the form of social gathering and recitation in their society which were conducted once in a month. Nontransmitted disease integrated post was usually scheduled after social gathering activities. However, although there was fund support from the citizen association, not all residents wanted to have examination due to lack of money. The officers of non-transmitted disease integrated post had not been able to receive patients who paid through Social Insurance Administration Board.

\section{CONCLUSION}

The implementation of non-transmitted disease integrated post is influenced by the interactions of team maker with target groups, the role of implementers, the performance of non-transmitted disease integrated post, and environment (culture, economy, and politic) in the community

\section{CONFLICT OF INTEREST}

The authors declare no conflict of interest.

\section{ACKNOWLEDGEMENT}

We would like to thank to the Head of the Sukoharjo Regency Health Office for giving research permission and the Coordinator of Village Midwives of Triyagan \& Laban for their cooperation.

\section{REFERENCES}

1. World Health Organization., WHO Global Observatory for eHealth. Legal frameworks for eHealth: based on the findings of the second global survey on eHealth. World Health Organization; 2012; 84.

2. Dinas Kesehatan Provinsi. Profil Dinas Kesehatan Provinsi Jawa Tengah. Semarang; 2015.

3. Rusdiyanti I. Factors That Influence The Activity Of Visited Integrated Posting Most Of Diseases In The Village. 2018; 1(2):518.

4. Prevention SFOR, Diseases COFN. Integrating mental health with other noncommunicable diseases. 2019;13-6.

5. Primiyani Y. Analisis Pelaksanaan Program Pos Pembinaan Terpadu Penyakit Tidak Menular di Kota Solok. J Kesehat Andalas. 2018; 8(2):399-406.

6. Fuadah DZ, Rahayu NF. Utilization Of Integrated Posted Cooperation (Posbindu) of Non-Communicable Disease of Patients with Hypertension. J Ners dan Kebidanan. 2018; 5(1) :20-8.

7. Oecan. Use of Healthcare Services by Patients with Non-Communicable Diseases in Nepal: A Qualitative Study with Healthcare Providers. 2017; 1-5.

8. Haniek,Umayana. Dukungan Keluarga dan 
Tokoh Masyarakat Terhadap Keaktifan Penduduk KKe Posbindu Penyakit Tidak Menular. 2015;11(1):96-101.

9. WHO. Integgrated Health Service -. 2008;(1):1-10.

10. Apatu E, Hamadi H, Abrams JA, Metzger IW, Spaulding A. Association between hospital community services and county population health in the USA. 2018;(April):1-9.

11. Kementerian Kesehatan RI. Petunjuk Teknis Pos Pembinaan Terpadu Penyakit Tidak Menular. Jakarta: Direktorat Jendral Pengendalian Penyakit Penyakit Tidak Menular; 2012.

12. Buabeng $\mathrm{C}$, Andoh. Factors influencing teachers, adoption and integration of information and communication technology into teaching: A review of the literature Charles Buabeng-Andoh. IJEDICT. 2012; 8(1):136-55.

13. Sunartyasih CMR, Linda B. Hubungan Kendala Pelaksanaan Posbindu Dengan Kehadiran Lasia. Pros SNaPP. 2019;195202.

14. Ratna DW, Savitri M. Faktor-faktor yang berhhubungan dengan pemanfaatan posbindu penyakit tidak menular (ptm) di wilayah kerja puskesmas kecamatan setiabudi kota jakarta selatan tahun 2018. J Kebijak Indones. 2018;7(2):49-56.

15. Kiting RP, Ilmi B. Faktor yang berhubungan dengan kinerja kader posbindu penyakit tidak menular. 2015;4(1):106-15. 